\title{
Diversity in Macrobenthic \& Algal Fauna of Limha Pond, Ghutku Bilaspur India
}

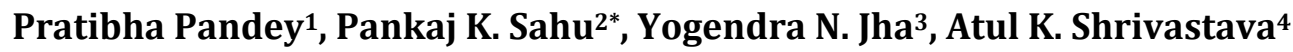 \\ ${ }^{1}$ Department of Zoology, Dr. C.V. Raman University Kota, Bilaspur, India \\ ${ }^{2}$ Department of Botany, Dr. C.V. Raman University Kota, Bilaspur, India \\ ${ }^{3}$ Department of Zoology, Govt. Science College Jhanjhgir, Champa, India \\ ${ }^{4}$ Directorate of Research Services, JNKVV, Jabalpur, India \\ Email: sahu.pankaj1@gmail.com
}

Received 14 November 2013; revised 23 December 2013; accepted 11 January 2014

Copyright (C) 2014 by authors and Scientific Research Publishing Inc.

This work is licensed under the Creative Commons Attribution International License (CC BY). http://creativecommons.org/licenses/by/4.0/

(c) (i) Open Access

\section{Abstract}

The present study reported on phytoplankton in comparison to the zooplankton in Limha Pond, Ghutku, Bilaspur. The phytoplankton represented in larger number of Cyanophyceae with least density of Dinophyceae and Chlorophyceac, and Bacillariophyceae is the second dominant group. The present study tried to discuss on the problem Macrobenthic fauna of Limha Pond, Ghutku Bilaspur and observed quantitative algal and faunal diversity i.e. phytoplankton (34 species), aquatic organism (6 species) Bacillariophyceae (8 species), Chlorophyceae (11 species), Euglenophyceae (6 species), Zooplankton (20 species), and Fish species (16 species). Present study revealed that Cyprinidae (carps) were the dominant fish and Catla was a major contributor among carps. The following species Catla catla, Labeo rohita, Cirrhinus mrigala, Labeo calbasu, Barbus tor and Cirrhinus reba etc. were noted in Limha pond, Ghutku, Bilaspur.

\section{Keywords}

Aquatic Community; Fishes; Algal Group; Limha

\section{Introduction}

The phytoplankton forms a very important component of the aquatic vegetation, occurring in all kinds of water bodies and consequently enjoying a worldwide distribution. Therefore, particularly in the recent past, numerous researchers from all parts of the globe have paid considerable attention to the study of the planktons. Macro benthic organisms form an important aspect of benthic studies in various fresh water ecosystems as they serve as

\footnotetext{
*Corresponding author.
}

How to cite this paper: Pandey, P., Sahu, P.K., Jha, Y.N. and Shrivastava, A.K. (2014) Diversity in Macrobenthic \& Algal Fauna of Limha Pond, Ghutku Bilaspur India. Open Journal of Marine Science, 4, 43-50.

http://dx.doi.org/10.4236/ojms.2014.42006 
food for aquatic organims and generally have high rates of reproduction i.e. phyla protozoa, porifera, coelentrata, annelida, arthropoda andmollusca. Aquatic communities usually consist of a large number of species populations, each species is linked more or less directly to others in the community, and the community as a whole changes constantly through the slow processes of ecological succession. Biodiversity is the most valuable but least appreciated resource, and it can be a key to the maintenance of the world [1].

According to WWF surveys [2], it was noticed that to control the extinction of species, race and the destruction of ecosystems should be controlled by the actions. Among the planktonic communities, the zooplanktones are the primary micro-consumers found to be dominated by Protozoa, Copepoda and Cladocera. The macrobenthos population living in water are more sensitive to environmental changes than any other organisms. Zooplankton communities have been investigated in numerous reservoirs, lakes, and shallow algal blooms [3] [4]. A few studies have been done on fish population dynamics, icthyo diversity and conservation of fishes in Lake Ecosystem in central and north east India [5]. The basic sampling or collection techniques of fresh water benthos are described by Lind [6], Welch [7] and Wetzel [8], and several keys for the identification of benthic macro invertebrates have been provided by Pennak [9]. An aquatic problem in Lentic community, biological productivity of the fresh water ecosystem was studied by [10]. The present study was done to discuss the diversity of macrobenthic fauna and algal groups/flora of Limha Pond, Ghutku Bilaspur.

\section{Materials and Methods}

\subsection{Study Site}

The present study was conducted in Limna pond, Ghutku, Bilaspur. Ghutku pond was located at $22^{\circ} 12^{\prime \prime}$ North latitude and $82^{\circ} 53^{\prime \prime}$ East longitudes and altitude is above $292 \mathrm{~m}$ asl. The pond design is very old fashioned in India as a small water body in which littoral zone is relatively large and limnetic and profundal zones are small or absent [11]. The pond is very economical and eco-friendly management to check the ground water level depletion by storing the rain water. There are 23,989 ponds spread over an area of 27,683 hectare in Bilaspur division while 3564 ponds spread in 5987 ha in Bilaspur about 80 feet long and 60 feet in width and the average 5" deep water level with rich flora and fauna. The pond is mainly rain-fed and receives the water of the cultivated land around it.

\subsection{Sampling Stations}

Sampling collections: Five sampling stations A-E were selected in present research work. Each station situated on the four banks of the pond i.e. east, west, north, south and they are four littoral zones and one Limnetic zone is situated in the middle of the pond. The water analysis were studied every month for the year in 2011-12 for Macrobanthic fauna as follows: Plankton biomass The water samples were collected from 5 sampling sites with the help of Ruther's sampler and filtered through bolting silk plankton having a diameter of $25 \mathrm{~cm}$ and a length of 50 $\mathrm{cm}$ with a mesh size of $60 \mathrm{~mm}$. The lower end of the cone of the plankton net was fitted to a glass tube of $50 \mathrm{ml}$ capacity. 10 liters of water from the sampling stations was passed through the plankton net. The filtrate was transferred to a marked glass, stopper bottles. The samples were further concentrated to $5 \mathrm{ml}$ by centrifugation at $2500 \mathrm{rpm}$. After sedimentation of phytoplankton the supernatant liquid was siphoned off and the sediment portion was preserved in $4 \%$ formaldehyde. The macro-benthic fauna was collected from the different sites and washed with normal saline solution and preserved in 5\% - 10\% formalin solution. Permanent slides were prepared and identified. The fishes were collected during the course of study preserved in 10\% formalin by giving a long incision on the ventral side. The identification of plankton was done using reference keys [12].

\subsection{Biological Analysis}

The macro-benthos and fishes were collected from five sampling stations with nets and for macrobenthos an Ekman's sampler was used. Fishes and algal organism were also washed with normal saline solution and preserved in $0.5 \%$ - $20 \%$ formalin solution. They were sorted out and their permanent slides were prepared after drying was identified. The big invertebrates and fishes were washed and kept in glassware's and preserved in $2 \%$ - 5\% formalin and corked. The collected macro benthos and fishes after identification were arranged systematically and their phylum, class, order, families, genus and species wise systematic position were given. Collection, identification and preservation of fishes-the fish population of the present from is very rich due to the presence of plank tonic population. The fishes of the Limha pond were collected at monthly interval with the help of local 
fishermen at all the five sampling stations The fishes collected from the pond were kept in $8 \%$ formalin for $48 \mathrm{hrs}$. Afterwards they were transferred to $5 \%$ formalin and preserved for detailed study. The identification of fishes was made with the help of Fauna by given by [13]. Formulae for fixative, stains and photographic solutions which were used here in this thesis and gave better results are given below: Normal Saline Solution: Sodium Chloride $0.67 \mathrm{gm}$ and distilled water $10 \mathrm{ml}$, Bouins fluid, Picric acid: Saturated $75 \mathrm{ml}$, Formaldehyde Acetic acid (Glacial) $25 \mathrm{ml}$ and Acetic acid glacial $5 \mathrm{ml}$.

\section{Observation \& Result}

The zooplankton community in the present investigation has been found to be dominated by the rotifer Brachionus angularis. So in the present study of species-abundance relationship, a broken stick model has been obtained in spite of the existence of a major dominant species throughout the study period. In present work discussed the comparative phytoplankton diversity in five different sites Limha Pond, Ghutku, Bilaspur, C.G. The present paper representing diversity in phytoplankton (34 species), algal organism (6 species) Bacillariophyceae (8 species), Chlorophyceae (11 species), Euglenophyceae (6 species), Zooplankton (20 species) and fishes (16 species). In present work tried to discuss on the problem Macrobenthic fauna of Limha Pond, Ghutku, Bilaspur C.G. (Figure 1).

Family wise diversity of Fish fauna with local name of fishes in Limha pond Ghutku, Bilaspur representing 16 species and Chana genus is most dominant genus with 3 species. Table 1, represents the phylum wise faunal

Table 1. Shows analysis of the zooplankton community of Limha pond, Bilaspur.

\begin{tabular}{|c|c|c|c|c|}
\hline SN. & Zoological Name & Phylum & Distribution sites & Status \\
\hline 1 & Anuraeopsis fissa Gosse. & Aschelminthes & A, B, C, D & Dominant \\
\hline 2 & Asplanchna brightwelli Grosse. & Aschelminthes & B, C, D, E & Common \\
\hline 3 & Asplanchnopus multiceps Schrgnk. & Aschelminthes & $\mathrm{B}, \mathrm{C}$ & Least \\
\hline 4 & Branchionus caudatus Barrois \& Daday. & Aschelminthes & A, C, D, F & Common \\
\hline 5 & Chromogaster ovalis Bergendal & Aschelminthes & $\mathrm{B}, \mathrm{C}, \mathrm{D}, \mathrm{E}$ & Common \\
\hline 6 & Cyclops viridis Jurine & Arthropoda & $\mathrm{A}, \mathrm{B}, \mathrm{D}, \mathrm{E}$ & Common \\
\hline 7 & Daphnia longispina Müller & Arthropoda & $\mathrm{A}, \mathrm{B}, \mathrm{C}, \mathrm{D}, \mathrm{E}$ & Dominant \\
\hline 8 & Epiphanes clavulata Ehrenberg & Aschelminthes & A, C, D, E & Common \\
\hline 9 & Euglena viridis Ehren & Protozoa & A, C, E & Moderate \\
\hline 10 & Gastropus sp. & Aschelminthes & $\mathrm{B}, \mathrm{C}, \mathrm{D}, \mathrm{E}$ & Common \\
\hline 11 & Hydra viridissima Pallas & Coelentrata & A, D, E & Moderate \\
\hline 12 & Keratella cochlearis Gosse & Aschelminthes & A, B, C, D & Dominant \\
\hline 13 & Keratella tropica Epstein & Aschelminthes & A, B, C, E & Common \\
\hline 14 & Monostyla bulla Goose & Aschelminthes & $\mathrm{A}, \mathrm{B}, \mathrm{C}, \mathrm{D}, \mathrm{E}$ & Dominant \\
\hline 15 & Paramaecium drotocephala & Platyhelminthes & A, C, D & Moderate \\
\hline 16 & Paramecium sp. & Protozoa & A, C, D & Moderate \\
\hline 17 & Pheretima posthuma & Annelida & $\mathrm{A}, \mathrm{B}, \mathrm{C}, \mathrm{D}, \mathrm{E}$ & Dominant \\
\hline 18 & Platyias quadricornis Ehrenberg & Aschelminthes & A, B, D, E & Common \\
\hline 19 & Polyarthra vulgaris Carlin & Aschelminthes & A, C, D, E & Common \\
\hline 20 & Scaridum longicaudum Muller & Aschelminthes & A, B, C, E & Common \\
\hline 21 & Spongilia sp. & Porifera & $\mathrm{B}, \mathrm{C}, \mathrm{E}$ & Moderate \\
\hline 22 & Synchaetape ctinata Ehrenberg & Aschelminthes & $\mathrm{A}, \mathrm{B}, \mathrm{C}, \mathrm{E}$ & Common \\
\hline 23 & Tubifex tubifex Muller & Annelida & $\mathrm{A}, \mathrm{B}, \mathrm{C}, \mathrm{D}, \mathrm{E}$ & Dominant \\
\hline 24 & Vorticella campanula Ehr. & Protozoa & B, C, E & Moderate \\
\hline
\end{tabular}

sp—not identified species. 


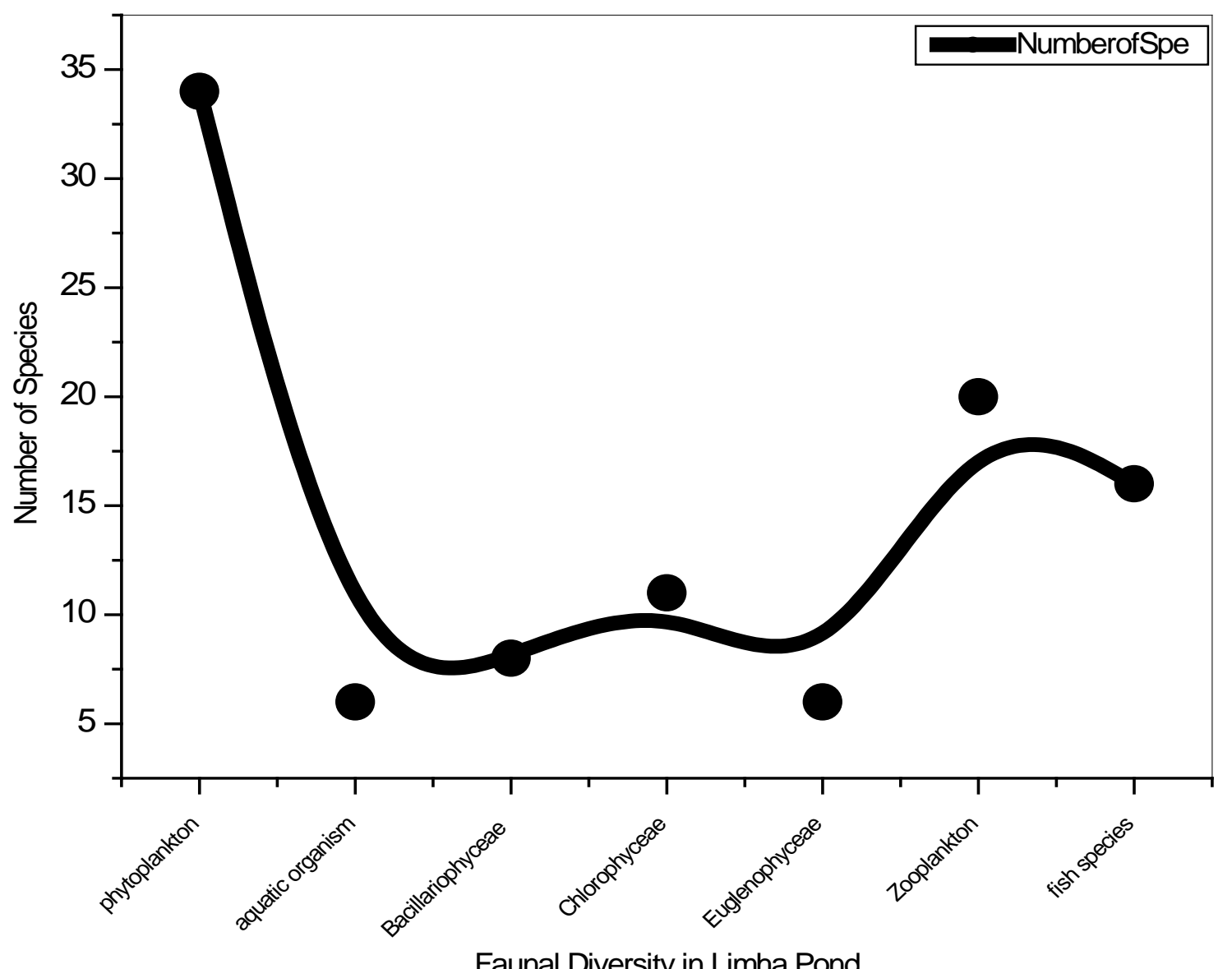

Figure 1. Represents the faunal species diversity in Limha Pond, Bilaspur CG.

diversity in sites with their status. In family wise distribution of fauna in the study site Cyprinidae is shows most dominant family with 8 species and 6 genera and Clariidae is less dominant with 1 species and 1 genus (Table 2).

\subsection{Phytoplankton}

The present study reported greater phytoplanktonic levels when compared to the zooplankton of Limha Pond, Ghutku. The phytoplankton represented in greatest number of Cyanophyceae and least density of Dinophyceae. The phytoplankton represented in the order of Chlorophyceae $>$ Bacillariophyceae $>$ Cyanophyceae $>$ Dinophyceae. The present study has reported Chlorophyceac domination next to the Bacillariophyceae. The Cyanophyceae was represented by 9 species. They were less dominant in percentage composition of all the four classes. Bacillariophyceae has been represented by 8 species. The diatoms were observed throughout the year. A progressive trend was noted from post monsoon to late spring and there was a decrease from summer and lowest concentration was observed (Table 3).

\subsection{Zooplankton}

The eight species of protozoa, twelve species of Rotifera, six species of Cladocera and three species of Copepoda, in all twenty four species of zooplankton were identified from this pond in 2011-12. The total number of zooplankton showed a remarkable trend of seasonal fluctuations. Two peaks were observed during the period of study, one of higher magnitude in the month of June and the other of lower magnitude in the month of December. During present investigation a direct correlation between zooplankton and phytoplankton has been recorded (Table 4). 
Table 2. Fish fauna of Limha pond Ghutku, Bilaspur taxonomic diagnosis of fishes collected.

\begin{tabular}{|c|c|c|c|}
\hline S. No. & Name & Family & Local Name \\
\hline 1. & Catla catla Ham. & Cyprinidae & - \\
\hline 2. & Channa marulius Ham. \& Buch. & Ophiocephalidae & - \\
\hline 3. & Channa punctatus Bloch & Ophiocephalidae & Girai \\
\hline 4. & Channa striatus Bloch. & Ophiocephalidae & - \\
\hline 5. & Cirrhinus mrigala Ham. & Cyprinidae & Nain \\
\hline 6. & Clarius batrachus Linn. & Clariidae & Mangur \\
\hline 7. & Heteropneustes fossils Bloch & Saccobranchidae & Singhi \\
\hline 8. & Labeo calbasu Ham. & Cyprinidae & Karaunchar \\
\hline 9. & Labeo rohita Ham. & Cyprinidae & Rohu \\
\hline 10. & Mystus bleekeri Day & Bagridae & - \\
\hline 11. & Mystus seenghala Sykes & Bagridae & Tenger \\
\hline 12. & Notopterus notopterus Pallas & Notopteridae & - \\
\hline 13. & Oxygaster bacaila Ham. & Cyprinidae & - \\
\hline 14. & Puntius chola Ham. & Cyprinidae & - \\
\hline 15. & Puntius sarana Ham. & Cyprinidae & - \\
\hline 16. & Wallgo attu Schn. & Cyprinidae & Padhni \\
\hline
\end{tabular}

-: Not available.

\section{Discussion}

In winter months, when the turbidity was minimum, zooplankton were not at peak; this may be due to low water temperature in Limha Pond, Ghutku. Group-wise pattern of the various zooplankton regarding their distribution and succession can be summarised as follows. Protozoans showed a remarkable fluctuation in frequency that was maximum in summer and minimum in winter because Difflugia sp. and Actinophrys sp. contributing as the major protozoans as they occupy the limnetic zone. Schonborn [14] observed the same findings. Arcella sp. was noted throughout the period of studies, which can withstand a wide range of physical and chemical factors. Paramaecium sp. and Opercularia sp. were dominant in late spring and summer months, favored by increased transparency and a favorable range of temperature. They were found to be absent in monsoon and again appeared in post monsoon months. Sarkar and Krishnamurthy [15] reported that protozoans always preferred clear waters.

Rutlner and Kolisko [16] reported that the maximum density of rotifers depends on the quantity of available nutrients and on the temperature. A range of high temperature and low concentration of nutrients, favoured a rise in rotifer density. Pillai et al., [17] observed that Copepoda were at the peak in June and the lowest density was observed in the month of October. Much has been stated about declining fish biodiversity and its conservation issues in Indian River Systems [18]-[22] and a lot of work was done on fishes of India [23]. Zooplanktons are bio-indicators of both pollution and trophic conditions of a water system and the growth of algae and other parasitic forms by feeding on them rich diversity of zooplankton indicates that the river is not polluted and it is suitable for fish production; this was checked by [21]. Present study revealed that Cyprinidae (carps) were the dominant fish and Catla was a major contributor among carps. Carps are fast growing fishes and popularly dominant fishes from point of view of their suitability. The species were noted to be suitable for Limha Pond, Ghutku, Catla catla, Labeo rohita, Cirrhinus mrigala, Labeo calbasu, Barbus tor and Cirrhinus reba etc. tail for the maintenance of the life.

\section{Acknowledgements}

Authors are thankful to Registrar, Dr. C. V. Raman University, Kota Bilaspur for providing support. Authors are 
Table 3. Representing species distribution of phytoplanktons.

\begin{tabular}{|c|c|c|}
\hline S. N. & Name of Phytoplanktons & Class \\
\hline 1 & Anabaena oryzae & Cyanophyceae \\
\hline 2 & Asphaerica sp. & Cyanophyceae \\
\hline 3 & Bacillaria sp. & Bacillariophyceae \\
\hline 4 & Curviceps & Cyanophyceae \\
\hline 5 & Lyngbya sp. & Cyanophyceae \\
\hline 6 & Merismopedia sps. & Cyanophyceae \\
\hline 7 & Microcystis aeruginosa & Cyanophyceae \\
\hline 8 & Navicula cuspedata & Bacillariophyceae \\
\hline 9 & Navicula indica & Bacillariophyceae \\
\hline 10 & Navicula pupula & Bacillariophyceae \\
\hline 11 & Navicula viridulu & Bacillariophyceae \\
\hline 12 & Ocillatoria chalybea & Cyanophyceae \\
\hline 13 & Pinnularia braunii & Bacillariophyceae \\
\hline 14 & Pinnularia tabellaria & Bacillariophyceae \\
\hline 15 & Scyponama hofmanni & Cyanophyceae \\
\hline 16 & Scyponama stuposum & Cyanophyceae \\
\hline 17 & Syendra ulna & Bacillariophyceae \\
\hline 18 & Volvox globatera & Chlorophyceae \\
\hline 19 & Ulothrix zonata & Chlorophyceae \\
\hline 20 & Cladophora fracta & Chlorophyceae \\
\hline 21 & Pithophora varia & Chlorophyceae \\
\hline 22 & Chaetophora elegans & Chlorophyceae \\
\hline 23 & Coleochate irireglaris & Chlorophyceae \\
\hline 24 & Oedogonium pussilum & Chlorophyceae \\
\hline 25 & Zygnema majus & Chlorophyceae \\
\hline 26 & Spirogvra brunca & Chlorophyceae \\
\hline 27 & Spirogyra hylina & Chlorophyceae \\
\hline 28 & Spirogyra microspora & Chlorophyceae \\
\hline 29 & Euglena acus & Euglenophyceae \\
\hline 30 & Euglena rigida & Euglenophyceae \\
\hline 31 & Euglena viridis & Euglenophyceae \\
\hline 32 & Phacus curicauda & Euglenophyceae \\
\hline 33 & Phacus longicauda & Euglenophyceae \\
\hline 34 & Phacus orbicularis & Euglenophyceae \\
\hline
\end{tabular}


Table 4. Represents distribution pattern of number of genus and species in different group.

\begin{tabular}{cccc}
\hline S No. & Family & Genus & Species \\
\hline 1 & Protozoa & 3 & 1 \\
2 & Porifera & 1 & 1 \\
3 & Arthropoda & 2 & 2 \\
4 & Annelida & 2 & 2 \\
5 & Aschelminthes & 14 & 14 \\
7 & Platyhelminthes & 1 & 1 \\
\hline
\end{tabular}

also thankful to Prof. P. K. Baipai Head, Department of Physics, Guru Ghasidas University, Bilaspur (C.G.) India for valuable suggestions.

\section{References}

[1] Wilson, E.O. (1992) Diversity of Life. W.W. \& Company, Inc., Norton, 424.

[2] World Wildlife Fund (2005) Beyond Belief: Linking Faiths and Protected Areas to Support Biodiversity Conservation. A research Report by WWF, Equilibrium and the Alliance of Religions and Conservation (ARC), Manchester.

[3] Abbasi, S.A. (1997) Wetlands of India (3)—Wetlands of India: Ecology and Threats (3), The Kuttiadi River Basin. Discovery Pub. House, New Delhi, 65-143.

[4] Sugunan, V.V. (1997) Fisheries and Management of Small Water Bodies in Seven Countries in Africa, Asia and Latin America. FAO Fisheries Circular, 933, 149.

[5] Jhingran, A.G. and Unnithan, V.K. (1990) Reservoir Fisheries in India. Proceedings of the National Workshop on Reservoir Fisheries, Manglore, 3-4 January 1990, 106-112.

[6] Lind, O.T. (1938) A Hand Book of Common Methods in Limnology. 2nd Edition, Kendall Hunt Pub Co., San Francisco, 236.

[7] Welch, P.S. (1952) Limnological Methods. Blakiston Co., Philadelphia.

[8] Wetzel, R.G. (1990) Land-Water Interfaces: Metabolic and Limnological Regulators. Verhandlungen der Internationale Vereinigung der Limnologie, 24, 6-24.

[9] Pennak, R.W. (1946) The Dynamics of Fresh-Water plankton Populations. Ecological Monographs, 16, 340-372. http://dx.doi.org/10.2307/1961640

[10] Wetzell, R.G. (2001) Limnology: Lake and River Ecosystem. 3rd Edition, Academic Press, San Diego.

[11] Odum, E.P. (1971) Fundamental of Ecology. 3rd Edition, W.B. Saunders, Philadelphia.

[12] Adoni, A., Joshi, D.G., Gosh, K., Chourasia, S.K., Vaishya, A.K., Yadav, M. and Verma, H.G. (1985) A Work Book on Limnology. Pratibha Publisher, Sagar.

[13] Shrivastava, G.J. (1968) Fish of Eastern Uttar Pradesh. Vishwa Vidhyalaya Prakashan, Varanasi.

[14] Schönborn, W. (1962) Dieökologie der Testaceen im Oligotrophen See, Dargestellt am Beispiel des Groben Stechlinsees. Limnologica Berlin, 1, 111-182.

[15] Sarkar, R. and Krishnamoorthi, K.P. (1977) Biological Method for Monitoring Water Pollution Level: Studies at Nagpur. Indian Journal Environment \& Health, 19, 132-139.

[16] Ruttner-Kolisko, A. (1974) Plankton Rotifers: Biology and Taxonomy. E. Schweizerbart’sche Verlagsbuchhandlung, Stuttgart, 146.

[17] Pillai, P.P. and Pillai, M.A. (1973) Tidal Influence on the Duel Variations of Zooplankton with Special Reference to Copepods in the Cochin Backwater. Journal of the Marine Biological Association of India, 15, 411-417.

[18] Anon (1995) Perspective Plan of NBFGR. Indian Council of Agriculture Research (ICAR), New Delhi.

[19] Menon, A.G.K. (1989) Conservation of Ichthyofauna of India. In: Jhingran, A.G. and Sugunan V.V., Eds., Conservation and Management of Inland Capture Fisheries Resources of India, Inland Fisheries Society of India, Barrackpore, 25-33. 
[20] Dubey, G.P. (1994) Endangered, Vulnerable and Rare Fishes of West Coast River Systems of India. In: Threatened Fishes of India, Natcon Pub. No. 4, Muzaffarnagar, 77-95.

[21] Kapoor, D., Mahanta, P.C. and Pandey, A.K. (1998) Ichthyo-Diversity of India: Status and Conservation. In Ponniah, A.G., Das, P. \& Verma, S.R., Eds., Fish Gen. Biodiversity Conservation, Natcon, Daya Publishing House, New Delhi, 5: 47-50.

[22] Kapoor, D. and Sarkar, U.K. (2005) Priority Research Components of NBFGR for Conservation of Indian Fish Biodiversity. Nat. Journal Fishing Chimes, 25, 110-113.

[23] Jayaram, K.C. (1981) The Freshwater Fishes of India. Hand Book, Zoological Survey of India, Calcutta. 